\title{
MANAJEMEN PEMBELAJARAN \\ PROGRAM KULLIYATUL MU'ALLIMIN AL-ISLAMIYAH (KMI) DI PONDOK PESANTREN MODERN AL-IHSAN BALEENDAH BANDUNG
}

\author{
Muhamad Priyatna \\ Dosen Tetap Prodi Pendidikan Agama Islam STAI Al Hidayah Bogor \\ priyatna.staia@gmail.com \\ priyatna@staialhidayahbogor.ac.id
}

\begin{abstract}
Abstrak
Penelitian ini bertujuan untuk mendeskripsikan manajemen pembelajaran Program Kulliyatul Mu'allimin Al-Islamiyah (KMI) di Pondok Pesantren Modern Al-Ihsan Baleendah Bandung, mulai dari perencanaan pembelajaran, pelaksanaan pembelajaran, dan evaluasi pelaksanaan pembelajaran. Metode penelitian ini menggunakan pendekatan deskriptif kualitatif. Subjek penelitian adalah ustad pendiri, ustad pengelola, dan santri. Objek penelitian ini adalah manajemen pembelajaran Program Kulliyatul Mu'allimin Al-Islamiyah (KMI) Pondok Pesantren Modern Al-Ihsan Baleendah Bandung. Adapun metode pengumpulan data menggunakan metode wawancara, observasi, dan dokumentasi. Hasil penelitian tentang manajemen pembelajaran Program di Pondok Pesantren Modern Al-Ihsan Baleendah Bandung menunjukkan bahwa; 1) Perencanaan pembelajaran telah dilengkapi silabus dan Rancangan Pelaksanaan Pembelajaran (RPP) lengkap dan didokumentasikan dengan baik dalam bentuk dokumen/buku satu, berisi Rencana Kerja Sekolah (RKS), memuat program kerja sekolah bidang kurikulm yang memberikan arah yang jelas dalam usaha mempersiapkan dan menyelenggarakan proses pembelajaran, serta dokumen/buku dua, berisi silabus, rpp, prota, promes. Program (KMI) Pondok Pesantren Modern Al-Ihsan Baleendah Bandung merupakan jenis pendidikan keagamaan yang diselenggarakan melalui jalur pendidikan formal Madrasah Tsanawiyah dan Madrasah Aliyah, sehingga Silabus dan RPP mengacu pendidikan formal, ditambah kurikulum muatan lokal diniyah khas pesantren serta program pembinaan ekstrakurikuler dan intrakurikuler bagi santri; Perencanaan pembelajaran disusun oleh Kepala Sekolah dengan melibatkan unsur yayasan, staf pengajar, pengelola, dan telah banyak mengalami perubahan, mengkuti dinamisasi kebijakan pemerintah dan permintaan stake holder; 2) pelaksanaan proses belajar mengajar dilaksanakan Senin-Sabtu, dimulai pukul 04.00-21.30. Aktivitas pembelajaran dimulai dengan pembukaan atau salam, ustad menyampaikan materi pelajaran yang menggunakan media pembelajaran seperti LCD, white board, dan spidol. Metode penyampaian materi menggunakan ceramah, demonstrasi, dan diakhiri dengan tanya jawab. Ustad menutup proses belajar mengajar dengan berdoa bersama dan mengucapkan salam penutup; dan 3) Evaluasi pembelajaran menggunakan evaluasi formatif, yaitu penilaian berupa tes yang dilakukan setelah satu pokok bahasan selesai dipelajari peserta didik dan evaluasi sumatif, yaitu penilaian berupa tes yang dilaksanakan setelah proses belajar mengajar selesai dalam jangka waktu tertentu, yaitu satu semester.
\end{abstract}

Kata kunci: pondok pesantren, pembelajaran, dan manajemen. 


\section{A. Pendahuluan}

Pesantren sama seperti satuan pendidikan lainnya, tidak bisa lepas dari kyai atau ustad sebagai pendidik, santri sebagai objek didik, masyarakat sebagai komunitas yang akan dikembangkan sebagai wujud kontribusi lulusan, dan kurikulum yang dijadikan pedoman pembelajaran untuk memproses para santri.

Oleh sebab itu, untuk meningkatkan nilai jual dan kualitas lulusan agar kompetitif di jenjang pendidikan berikutnya, pondok pesantren juga menerapkan kurikulum nasional. Pada praktiknya, tidak sekadar memberikan materi pendidikan agama Islam saja, tetapi juga ditambah dengan materi pelajaran umum untuk menambah wawasan anak asuhnya, sehingga kompetensi alumni yang dihasilkan nanti mampu mengintegrasikan keilmuan agama Islam dengan ilmu pengetahuan dan teknologi yang berkembang cepat di luar.

Menurut Sulthon Masyhud ${ }^{1}$, permasalahan pondok pesantren adalah mengembangkan model pendidikan untuk meningkatkan kualitas sumber daya manusia atau santri merupakan isu aktual yang harus diperbincangkan. Pentingnya pembahasan topik ini tidak bisa dilepaskan dengan dua potensi besar yang melekat pada pesantren, yaitu potensi pendidikan dan pengembangan masyarakat.

Sejak 2004 diberlakukan desentralisasi yang berarti berkurangnya peran pemerintah pusat, membuat setiap daerah mempunyai kewenangan lebih dari segi kebijakan dan pengelolaan aset. Kebijakan

${ }^{1}$ Sulthon Masyhud dan Khusnurdilo. Manajemen Pondok Pesantren. (Jakarta: Diva Pustaka, 2003). hlm. ini membuka peluang pondok pesantren untuk dijadikan mitra pemerintah daerah sebagai pelaksana proses belajar mengajar yang setara dengan sekolah formal. Syaratnya sumber daya manusia, fasilitas, dan kurikulum harus sesuai delapan standar nasional pendidikan sebagaimana tertuang dalam Peraturan Pemerintah No.19/Tahun 2005, yaitu standar isi, proses, kompetensi lulusan, pendidik dan tenaga kependidikan, sarana prasarana, pengelolaan, pembiayaan, dan penilaian.

Dalam prinsip penyelenggaraan pesantren sebagaimana tertera dalam Peraturan Pemerintah No. 17/Tahun 2010 tentang Pengelolaan dan Penyelenggaraan Pendidikan pada Pasal 102 ayat 3 ditegaskan "pendidikan nonformal diselenggarakan berdasarkan prinsip dari, oleh, dan untuk masyarakat". Artinya mengacu amanat konstitusi di atas, proses perencanaan dan pengembangan pembelajarannya dapat dibuat sesuai dengan potensi dan kemampuan pesantren, tetapi jika ingin institusi pendidikan seperti pesantren mempunyai manajemen pembelajaran yang baik, beberapa perencanaan pembelajaran di atas perlu dilengkapi agar proses pembelajaran terlaksana dengan baik.

Artinya pesantren sebagai salah satu jenis pendidikan keagamaan dapat mengembangkan kurikulum dan kegiatan pembelajaran sesuai dengan kemampuan dan keunikannya sendiri. Mengingat belum banyaknya karya tulis yang mengulas tentang manajemen pembelajaran di pesantren, penulis mencoba untuk melakukan penelitian ini untuk mendeskripsikan kondisi, tantangan, dan pelaksanaan manajemen pembelajaran di 
jalur pendidikan nonformal khususnya pesantren.

Berdasarkan uraian di atas, penulis ingin meneliti manajemen pembelajaran Program Kulliyatul Mu'allimin AlIslamiyah (KMI) di Pondok Pesantren AlIhsan Baleendah Bandung.

\section{B. Identifikasi Masalah}

Mencermati argumentasi di atas, maka dapat diidentifikasi beberapa masalah sebagai berikut:

1. Kurikulum Nasional yang sering berganti.

2. Perubahan pada kurikulum nasional, berpengaruh juga pada manajemen pembelajaran yang diberikan kepada santri.

3. Opini masyarakat terhadap kurikulum pembelajaran pesantren sebagai tempat belajar agama saja, sehingga menghasilkan output lulusan yang tidak memiliki keterampilan hidup yang sesuai dengan kebutuhan kekinian masyarakat.

\section{Batasan Masalah}

Merujuk pada masalah yang diteliti, dengan maksud memfokuskan kajian dan pokok persoalan yang akan dijawab, maka penulis memfokuskan pada bagaimana manajemen pembelajaran Program Kulliyatul Mu'allimin Al-Islamiyah (KMI) di Pondok Pesantren Al-Ihsan Baleendah Bandung.

\section{Rumusan Masalah}

Berdasarkan identifikasi masalah di atas, maka rumusan masalah yang akan dideskripsikan dalam penelitian ini adalah:
Bagaimana manajemen pembelajaran Program Kulliyatul Mu'allimin AlIslamiyah (KMI) di Pondok Pesantren AlIhsan Baleendah Bandung?

\section{E. Pertanyaan Penelitian}

Berdasarkan rumusan masalah di atas, maka pertanyaan penelitian dalam penelitian ini adalah:

1. Bagaimana perencanaan pembelajaran (KMI) di Pondok Pesantren Al-Ihsan Baleendah Bandung?

2. Bagaimana pelaksanaan pembelajaran Program (KMI) di Pondok Pesantren Al-Ihsan Baleendah Bandung?

3. Bagaimana evaluasi pelaksanaan pembelajaran (KMI) di Pondok Pesantren Al-Ihsan Baleendah Bandung?

\section{F. Tujuan Penelitian}

Berdasarkan judul penelitian di atas, dapat diketahui tujuan penelitian ini adalah:

1. Untuk mendeskripsikan perencanaan pembelajaran Program (KMI) di Pondok Pesantren Al-Ihsan Baleendah Bandung.

2. Untuk mendeskripsikan pelaksanaan pembelajaran pendidikan Program (KMI) di Pondok Pesantren Al-Ihsan Baleendah Bandung.

3. Untuk mendeskripsikan evaluasi pembelajaran Program (KMI) di Pondok Pesantren Al-Ihsan Baleendah Bandung.

\section{G. Manajemen Pembelajaran di Pesantren}

\section{Pengertian Pesantren}

Pondok pesantren merupakan bentuk pendidikan khas Indonesia. Jauh sebelum 
Indonesia ada, pondok pesantren yang didirikan para pemuka dakwah Islam telah menyebar luas di Nusantara. Tujuan didirikannya pondok pesantren adalah sebagai tempat proses belajar mengajar agama Islam, menjaganya, dan menyebarkannya.

Oleh sebab itulah, Nasir mendefinisikan pondok pesantren sebagai lembaga keagamaan yang memberikan pendidikan dan pengajaran serta pengembangan dan menyebarkan ilmu agama Islam. $^{2}$

Secara etimologi atau asal katanya, Soejono Prasojo dalam Nasir menyatakan pondok pesantren merupakan kata gabungan dari pondok dan pesantren. Istilah pondok berasal dari kata funduk, dari bahasa Arab yang berarti rumah penginapan, sedangkan pesantren secara etimologi artinya pe-santri-an yang artinya tempat santri. ${ }^{3}$

Pendapat lainnya secara lebih luas disampaikan Zamakhsyari Dhofier, ${ }^{4}$ pondok pesantren adalah sebuah asrama pendidikan tradisional yang para siswanya semua tinggal bersama dan belajar di bawah bimbingan guru yang lebih dikenal dengan sebutan kiai dan mempunyai asrama untuk tempat menginap santri. Santri tersebut berada dalam komplek yang juga menyediakan masjid untuk beribadah, ruang untuk belajar dan kegiatan keagamaan lainnya. Komplek ini biasanya dikelilingi oleh tembok

\footnotetext{
${ }^{2}$ Ridlwan Nasir. Mencari Tipologi Format Pendidikan Ideal: Pondok Pesantren di Tengah Arus Perubahan. (Yogyakarta: Pustaka Pelajar, 2005). hlm. 80.

${ }^{3}$ Ridlwan Nasir. Mencari Tipologi Format Pendidikan Ideal. hlm. 80 .

${ }^{4}$ Zamakhsyari Dhofier. Tradisi Pesantren: Studi tentang Pandangan HidupKyai. Jakarta: LP3S, 1983). hlm. 18.
}

untuk dapat mengawasi keluar masuknya para santri sesuai dengan peraturan yang berlaku.

Berdasarkan teori di atas, dapat disimpulkan pondok pesantren adalah tempat untuk mempelajari keilmuan Islam dengan cara bahwa santri tinggal di suatu tempat untuk belajar dengan waktu pendidikan yang telah ditentukan. Proses pendidikannya dibimbing oleh kyai atau ustad dengan tata aturan yang mengikat para santri untuk belajar dan beraktivitas.

Ada berbagai klasifikasi pondok pesantren yang memiliki corak masingmasing dilihat dari organisasi pendiri dan orientasi lulusan yang akan dicetak. Menurut Imam Sarkowi dalam Jurnal Pembaruan Pemikiran Pesantren yang diterbitkan dalam edisi online. Ada beberapa jenis pondok pesantren sebagai berikut: $^{5}$

a. Pondok Pesantren Salaf/Klasik: yaitu pondok pesantren yang di dalamnya terdapat sistem pendidikan salaf (weton dan sorogan), dan sistem klasikal (madrasah) salaf. Biasanya pondok pesantren Nahdatul Ulama menerapkan demikian. Sorogan adalah metode proses belajar mengajar, di mana santri membaca kitab dan kyai atau ustad mengoreksinya. Sedangkan weton adalah sebaliknya.

b. Pondok Pesantren Semi Berkembang: yaitu pondok pesantren yang di dalamnya terdapat sistem pendidikan salaf (weton

\footnotetext{
5 Imam Sarkowi. Pembaharuan Pemikiran Pesantren dalam Vivit Nur Arista Putra, Manajemen Pembelajaran di Pondok Pesantren Al Ihsan Baleendah Bandung, (UNY: Yogyakarta, 2013). hlm. 15.
} 
dan sorogan), dan sistem klasikal (madrasah) swasta dengan kurikulum $90 \%$ agama dan $10 \%$ umum.

c. Pondok Pesantren Berkembang: yaitu pondok pesantren seperti semi berkembang, hanya saja sudah lebih bervariasi dalam bidang kurikulumnya, yakni $70 \%$ agama dan 30\% umum. Di samping itu juga diselenggarakan madrasah SKB Tiga Menteri dengan penambahan diniyah.

d. Pondok Pesantren Khalaf/ Modern: yaitu seperti bentuk pondok pesantren berkembang, hanya saja sudah lebih lengkap lembaga pendidikan yang ada di dalamnya, antara lain diselenggarakannya sistem sekolah umum dengan penambahan diniyah (praktek membaca kitab salaf), perguruan tinggi (baik umum maupun agama), bentuk koperasi dan dilengkapi dengan takhasus (bahasa Arab dan Inggris), sebagai contoh pondok pesantren yang didirikan Muhammadiyah.

e. Pondok Pesantren Ideal: yaitu sebagaimana bentuk pondok pesantren modern hanya saja lembaga pendidikan yang ada lebih lengkap, terutama bidang keterampilan yang meliputi pertanian, teknik, perikanan, perbankan, dan benar-benar memperhatikan kualitasnya dengan tidak menggeser ciri khusus kepesantrenannya yang masih relevan dengan kebutuhan masyarakat dan perkembangan zaman.
Mencermati klasifikasi di atas, dapat dikatakan Pondok Pesantren Al-Ihsan Baleendah Bandung, masuk dalam kategori Pondok Pesantren modern, dikarenakan bentuk pondok pesantren berkembang, hanya saja sudah lebih lengkap lembaga pendidikan yang ada di dalamnya, antara lain diselenggarakannya sistem sekolah umum dengan penambahan diniyah (praktek membaca kitab salaf), perguruan tinggi (baik umum maupun agama), bentuk koperasi, dan dilengkapi dengan takhasus (bahasa Arab dan Inggris).

Pondok pesantren sebagai tempat menuntut ilmu mempunyai beberapa fungsi sebagaimana dijelaskan Azyumardi Azra sebagaimana dikutip Sulthon Masyhud menerangkan fungsi pondok pesantren ada tiga, yaitu transfer ilmu-ilmu Islam, pemeliharaan tradisi Islam, dan reproduksi ulama. Pesantren juga menyelenggarakan pendidikan nonformal berupa madrasah diniyah yang mengajarkan ilmu agama Islam. ${ }^{6}$

\section{Pengertian Pembelajaran}

Pembelajaran merupakan substansi penting dalam kegiatan di sekolah. Oleh karena itu, para pendidik dituntut untuk kreatif dan inovatif untuk menyampaikan pengetahuan. Menurut Suprihadi Saputro, pembelajaran merupakan istilah lain dari kata pengajaran merujuk pada makna tentang hal mengajar. Pembelajaran didefinisikan sebagai kegiatan guru yang mendorong terjadinya aktivitas belajar. ${ }^{7}$

\footnotetext{
${ }^{6}$ Sulthon Masyhud dan Khusnurdilo. Manajemen Pondok Pesantren. hlm. 90.

7 Suprihadi Saputro. Strategi Pembelajaran. (Malang, Departemen Pendidikan Nasional, Universitas Negeri Malang, 2000). hlm. 1.
} 
Berdasarkan kajian tersebut, penulis menyimpulkan pembelajaran adalah suatu kegiatan mengondisikan lingkungan belajar dengan tujuan agar peserta didik tergerak untuk mempelajari sesuatu yang baru dan tergerak melakukannya sesuai dengan apa yang diinginkan pengajar. Pembelajaran di pesantren adalah bagaimana peran ustad dan pengurus pesantren untuk mengatur lingkungan belajarnya agar para santri terdorong untuk belajar demi tercapainya kompetensi lulusan yang ditentukan sebelumnya.

\section{Komponen Perencanaan Pembelajaran}

Komponen perencanaan pembelajaran adalah aspek penting yang harus diperhatikan karena berkaitan dengan aktivitas pembelajaran itu sendiri, yang berhubungan dengan kebutuhan pendidik dalam mendidik peserta didik. Menurut Alben Ambarita, ${ }^{8}$ komponen pembelajaran ini merupakan hal yang utama dalam interaksi guru dan peserta didik untuk menyampaikan konsep atau keterampilan agar dikuasai peserta didik. Kepala sekolah diharapkan mampu mengkoordinasikan pendidik dalam perencanaan dan pelaksanaan pembelajaran:
a. Penyusunan silabus, program semester. tahunan, program semester, dan mid
b. Penyusunan desain pembelajaran peserta didik.
c. Penguasaan dan implementasi metode pembelajaran.
d. Penilaian sebagai uji kompetensi.
e. Kontrol dalam pencapaian indikator keberhasilan peserta didik.

8 Alben Ambarita, Manajemen Pembelajaran. (Jakarta: Departemen Pendidikan Nasional, 2006). hlm. 75.

\section{Pelaksanaan Pembelajaran}

Menurut Syaiful Bahri dan Aswan Zain, pelaksanaan pembelajaran adalah suatu kegiatan yang bernilai edukatif mewarnai interaksi yang terjadi antara guru dan siswa. Interaksi yang bernilai edukatif dikarenakan pelaksanaan pembelajaran yang dilakukan diarahkan untuk mencapai tujuan tertentu yang telah dirumuskan sebelum pelaksanaan pembelajaran dimulai. ${ }^{9}$

Teori lainnya menurut Nana Sudjana pelaksanaan pembelajaran adalah proses yang diatur sedemikian rupa menurut langkah-langkah tertentu agar pelaksanaan mencapai hasil yang diharapkan. ${ }^{10}$

Berdasarkan beberapa definisi di atas dapat disimpulkan pelaksanaan pembelajaran adalah interaksi pendidik dan peserta didik di lingkungan belajar yang bernilai edukatif dengan memanfaatkan sarana dan prasarana belajar untuk mencapai tujuan pembelajaran yang sebelumnya telah dirumuskan.

\section{Tahapan-tahapan Pelaksanaan Pembelajaran}

Agar pelaksananaan pembelajaran sistematis maka para pakar pendidikan membaginya kedalam tiga tahapan. Menurut Mulyasa pelaksanaan pembelajaran terdiri dari kegiatan awal, inti, dan akhir yang rinciannya adalah: ${ }^{11}$

\section{a. Kegiatan awal}

1) Menciptakan lingkungan dengan salam pembuka dan berdoa.

${ }^{9}$ Syaiful Bahri dan Azwan Zain. Setrategi Belajar Mengajar. (Jakarta: Rineka Cipta. 2010). hlm. 1.

10 Nana Sudjana. Dasar-Dasar Proses Belajar Mengajar. (Bandung: Sinar Baru Algensindo, 2010). hlm. 136

11 Mulyasa. Kurikulum Tingkat Satuan Pendidikan. (Bandung: PT Remaja Rosdakarya, 2006). hlm. 243. 
2) Pretes, yaitu peserta didik menjawab beberapa pertanyaan tentang materi pelajaran yang akan diajarkan.

3) Menghubungkan materi yang telah dimiliki peserta didik dengan bahan atau kompetensi baru.

\section{b. Kegiatan inti}

1) Pengorganisasian sebagai contoh membentuk kelompok besar atau kecil.

2) Prosedur pembelajaran contohnya terdiri dari:

a) Tanya jawab.

b) Kegiatan pengamatan.

c) Melaporkan hasil pengamatan.

d) Diskusi kelompok.

e) Menyimpulkan hasil pengamatan dan diskusi.

f) Memberi contoh penerapan konsep dalam kehidupan sehari-hari.

g) Membuat rangkuman.

\section{c. Kegiatan akhir}

1) Untuk membentuk kompetensi dan memantapkan peserta didik terhadap kompetensi yang telah dipelajari bisa dilakukan dengan perenungan.

2) Post tes bisa dilakukan lisan atau tertulis.

3) Menutup pembelajaran dengan berdoa.

Berdasarkan teori di atas, penulis menggunakan teori Mulyasa dengan pembagian kegiatan awal, kegiatan inti, dan kegiatan akhir untuk mengetahui pelaksanaan pembelajaran Program (KMI) di Pondok Pesantren Al-Ihsan Baleendah Bandung.

\section{Evaluasi Pembelajaran}

Evaluasi pembelajaran dilakukan untuk mengetahui apakah perencanaan pembelajaran yang telah dirumuskan dan direalisasikan dalam pelaksanaan pembelajaran telah tercapai atau belum. Pada UU No. 20/Tahun 2003 tentang Sistem Pendidikan Nasional Pasal 58 Ayat 1 berbunyi "evaluasi hasil belajar peserta didik dilakukan oleh pendidik untuk memantau proses, kemajuan, dan perbaikan hasil belajar peserta didik secara berkesinambungan".

Pengertian lainnya dicetuskan Suharsimi Arikunto, menerangkan evaluasi proses pengajaran adalah suatu rangkaian kegiatan yang dilakukan dengan sengaja untuk melihat atau mengetahui seberapa tinggi tingkat keberhasilan dari kegiatan yang direncanakan. ${ }^{12}$

Berdasarkan definisi para ahli di atas, dapat disimpulkan evaluasi pembelajaran adalah aktivitas yang dilakukan kegiatan pendidikan untuk mengukur sejauh mana tujuan pembelajaran tercapai.

\section{H. Pendekatan Penelitian}

Pendekatan penelitian sangat penting bagi peneliti untuk membantu menganalisia data penelitian yang diperoleh. Sugiyono membedakan pendekatan penelitian menjadi kualitatif dan kuantitatif. Penelitian ini menggunakan pendekatan penelitian kualitatif karena menjelaskan mengenai informasi yang diteliti dan dikritisi secara faktual. $^{13}$

Menurut Suharsimi Arikunto penelitian deskriptif adalah penelitian yang

12 Suharsimi Arikunto. Dasar-Dasar Evaluasi Pendidikan. (Jakarta: PT Bumi Aksara. 2005). hlm. 290.

13 Sugiyono. Metode Penelitian Kuantitatif Kualitatif dan $R \&$ D . (Bandung: Alfabeta. 2007). hlm. 12. 
memberikan informasi data yang diamati dan tidak bertujuan menguji hipotesis serta hanya menyajikan dan menganalisis data agar bermakna dan komunikatif. ${ }^{14}$

Mengacu referensi di atas, dapat disimpulkan jenis penelitian yang dipakai dalam penelitian ini adalah penelitian deskriptif dengan pendekatan penelitian kualitatif.

Pada penelitian ini akan dijabarkan mengenai manajemen pembelajaran Program (KMI) di Pondok Pesantren AlIhsan Baleendah Bandung.

\section{Objek Penelitian}

Sebagai peneliti perlu memahami tentang objek penelitian dan batasannya. Menurut Tatang M. Amirin, objek penelitian adalah sifat keadaan (attributes) dari sesuatu benda, orang, atau keadaan, yang menjadi pusat perhatian atau sasaran penelitian. Sifat keadaan yang dimaksud bisa berupa kuantitas, dan kualitas (benda, orang, dan lembaga), bisa berupa perilaku, kegiatan, pendapat, pandangan penilaian, sikap pro-kontra atau simpati-antipati, keadaan batin, dan sebagainya. Bisa pula berupa proses dan hasil proses lembaga. ${ }^{15}$

Objek penelitian ini adalah manajemen pembelajaran Program (KMI) di Pondok Pesantren Al-Ihsan Baleendah Bandung.

\section{J. Informan Penelitian}

Proses penelitian membutuhkan informasi dari orang tentang objek penelitian yang dipilih. Mengenai hal ini,

${ }^{14}$ Suharsimi Arikunto. Prosedur Penelitian Suatu Pendekatan Sistem. (Jakarta: PT Rineka Cipta. 2006). hlm. 83.

${ }^{15}$ Tatang M. Amirin. Subjek Penelitian, Responden Penelitian, dan Informan (Narasumber) Penelitian, diakses dari https://tatangmanguny. wordpress.com/ 2009/04/21/subjek-responden-dan-informan-penelitian/ pada Selasa, tanggal 25 Oktober 2016. pukul 11.07 WIB.
Tatang M. Amirin mendefiniskan informan (narasumber) penelitian adalah seseorang yang memiliki informasi data mengenai objek yang sedang diteliti, dimintai informasi mengenai objek penelitian tersebut. Lazimnya informan atau narasumber penelitian ini ada dalam penelitian yang subjek penelitiannya berupa "kasus" (satu kesatuan unit), antara lain yang berupa lembaga atau organisasi atau institusi (pranata) sosial. Di antara sekian banyak informan tersebut, ada yang disebut narasumber kunci, yaitu seorang ataupun beberapa orang, yaitu orang atau orang-orang yang paling banyak menguasai informasi (paling banyak tahu) mengenai objek yang sedang diteliti tersebut. $^{16}$

Narasumber kunci pada penelitian untuk mengetahui manajemen pembelajaran Program (KMI) di Pondok Pesantren Al-Ihsan Baleendah Bandung adalah ustad pendiri, ustad pengelola, dan beberapa santri di sana dimintai tanggapan untuk mengetahui objek penelitian secara menyeluruh.

\section{K. Teknik Pengumpulan Data}

Untuk memperoleh data, menurut Patton ada tiga macam metode pengumpulan data dalam penelitian kualitatif yaitu wawancara, observasi, dan dokumentasi ${ }^{17}$.

\section{Wawancara}

Wawancara merupakan salah satu cara untuk memperoleh data penelitian. Biasanya wawancara menggunakan alat bantu seperti rekaman, hancycamp, atau

${ }^{16}$ Tatang M. Amirin. Subjek Penelitian, Responden Penelitian, dan Informan (Narasumber) Penelitian. 2009.

17 Asmadi Alsa. Pendekatan Kuantitatif dan Kualitatif serta Kombinasinya dalam Penelitian Psikologi. (Yogyakarta: Pustaka Pelajar. 2007). hlm. 40. 
alat tulis. Moleong mendefiniskan wawancara adalah percakapan dengan maksud tertentu. Maksudnya adalah pewawancara mengajukan beberapa pertanyaan kepada pihak yang diwawancarai untuk membantu menambah data penelitian. Proses tanya jawab ini dapat berupa lisan dan tulisan secara objektif tanpa ada kiat atau trik pertanyaan untuk memengaruhi responden. ${ }^{18}$ Menurut Suharsimi Arikunto ada dua pedoman wawancara yaitu: ${ }^{19}$

a. Pedoman wawancara terstruktur dengan menyediakan pertanyaan yang disusun secara rinci sehingga menyerupai check list. Pewawancara hanya mencentang tanda $\mathrm{v}$ (check) pada tempat yang disediakan.

b. Pedoman wawancara tidak terstruktur yang memuat garis besar hal yang akan ditanyakan. Jika menggunakan pedoman ini, dituntut kreativitas pihak pewawancara.

Adapun dalam penelitian ini metode wawancara yang digunakan adalah tidak terstruktur dengan melakukan wawancara dengan ustad pendiri, dua ustad pengelola, dan santri. Wawancara tidak terstruktur ini dilakukan untuk mengetahui penyusunan silabus dan RPP, proses belajar mengajar, dan evaluasi pembelajaran yang dilakukan di Program (KMI) Pondok Pesantren Al-Ihsan Baleendah Bandung.

18 Lexy J. Moleong. Metodologi Penelitian Kualitatif. (Bandung: PT Remaja Rosdakarya. 2005). hlm. 185 . 202.

\section{Observasi}

Aktivitas observasi tidak hanya mengamati saja. Jika hanya mengamati tanpa menganalisis seperti turis. Begitupun sebaliknya, jika hanya menganalisis tanpa melihat dapat disebut mengkhayal. Oleh sebab itu, ahli pendidikan Suharsimi Arikunto menyatakan observasi adalah usaha sadar untuk mengumpulkan data yang dilakukan sistematis dengan menggunakan prosedur yang terstandar. Teknik ini menuntut pengalaman empiris peneliti ketika berinteraksi dengan objek penelitian sehingga hasil pengalaman tersebut dapat dituangkan untuk menambah data penelitian. ${ }^{20}$ Hal yang diobservasi di Program (KMI) di Pondok Pesantren Al-Ihsan Baleendah Bandung adalah proses belajar mengajar sehari-hari dan evaluasi pembelajarannya.

\section{Dokumentasi}

Aktivitas dokumentasi tidak sekadar foto-foto tetapi lebih dari itu. Moleong menjelaskan, dokumentasi adalah setiap bahan tertulis atau file yang terdiri dari dokumen pribadi seperti buku harian, surat pribadi, autografi, dokumen resmi seperti memo, pengumuman laporan rapat, aturan lembaga masyarakat dan lain-lain. $^{21}$ Dokumen yang dianalisis dalam penelitian ini adalah buku panduan kurikulum dan buku serta artikel pada website terkait profil dan sejarah singkat Pondok Pesantren Al-Ihsan Baleendah Bandung.

\footnotetext{
${ }^{20}$ Suharsimi Arikunto. Prosedur Penelitian. hlm. 197.

21 Lexy J. Moleong. Metodologi Penelitian Kualitatif. hlm. 16.
} 


\section{Profil Pondok Pesantren Al-Ihsan Baleendah Bandung}

\section{Sejarah ${ }^{22}$}

Dimulai oleh kedatangan tiga orang alumni Pondok Modern Gontor, yaitu Ust. Mahrus As'ad, Ust. Dede Rohanda, dan Ust. Suismanto menghadap ke alumni senior, yaitu K.H. Ujang Muhammad HM. yang kebetulan pada saat itu beliau sedang memimpin sebuah lembaga pendidikan umum (SMP/SMA) yang berada di J1. Denki Selatan V Kodya Bandung. Mereka bertiga mengutarakan maksud untuk mendirikan sebuah lembaga pendidikan Islam yang bernuansa Gontor dan berasrama penuh, yang tidak mengizinkan santrinya pulang pergi, sehingga mengganggu proses pendidikan dan pengajaran.

Untuk merealisasikan ide yang mulia ini, maka pada tanggal 17 Juli 1989 secara resmi didirikan sebuah lembaga Pendidikan Islam ala Gontor, yang diberi nama Pondok Modern Miftahul Jannah, dengan jenjang pendidikan KMI (Kulliyatul Mu'allimin al-Islamiyah) yang masa belajarnya enam tahun. Lembaga itu terletak di Jl. Denki Selatan V Regol Bandung, tepatnya di lokasi SMP/SMA Sebelas Maret.

Lokasi pesantren yang berada di Jl. Denki Selatan V sangat sempit dan sulit untuk dikembangkan. Para santri berbaur dengan murid SMP dan SMA yang mengakibatkan pelaksanaan proses

${ }^{22}$ Wawancara langsung dengan KH. U. Muhamad HM. dan Dr. H. Mahrus As'ad, M. Ag., Sabtu, 29 Oktober 2016, pukul 08.17-09.00 WIB, kediaman KH. U. Muhamad HM., Jl. Adipati Agung No. 40 Baleendah Bandung. Lihat juga website resmi Pondok Pesantren Allhsan Baleendah Bandung Jawa Barat http:// pesantrenalihsan be.or.id/index.php?mod=content\&act= static\&id=1\&menu_id=13, diakses pada Senin, 17 Oktober 2016, pukul 10.47 WIB. pendidikan, pengajaran, disipilin bahasa, dan disiplin-disiplin lainya tidak bisa berjalan secara maksimal.

Berkat usaha maksimal yang disertai dengan doa dan mujahadah, ditemukan lokasi baru yang dirasa lebih tepat untuk lokasi Pondok, yaitu di komplek Masjid Agung Al-Muhajirin yang berada di kecamatan Baleendah Bandung Selatan. Maka pada tanggal 8 September 1991, berhijrahlah guru dan santri dari Jl. Denki Selatan V Bandung ke komplek Masjid Agung Al-Muhajirin Baleendah.

Setelah setengah tahun berada di Baleendah, nama Pondok Pesantren Modern Miftahul Jannah dirubah menjadi "Darunnadwah", nama ini diambil dari kata Baleendah yang diterjemahkan ke dalam Bahasa Arab. Nama Darunnadwah hanya berjalan selama setengah tahun, karena setelah dikaji dengan seksama nama tersebut kurang relevan dengan tujuan dan cita-cita pondok. Hal itu berkenaan dengan nama sebuah kampung di zaman Nabi yang digunakan oleh kafir Quraisy sebagai tempat berkumpul mengatur strategi untuk menghancurkan umat Islam. Akhirnya setelah diadakan musyawarah pengurus pesantren, nama Darunnadwah berubah kembali menjadi "Miftahul Jannnah", dan pada tahun 1994 berubah menjadi Pondok Modern

\section{Al-Ihsan Baleendah.}

Pondok Pesantren Modern Al-Ihsan sejak pindah ke Baleendah tahun 1991 sampai Juni 2001 dipimpin oleh tiga orang pimpinan yang disebut Trimurti, mereka adalah:

1. K.H. U. Muhammad HM Karawang

2. Drs. H. Maulana Ibrahim Kuningan 
3. Dr. H. Mahrus As'ad, M. Ag. Bojonegoro

Ketiganya adalah alumnus Pondok Modern Gontor Ponorogo Jawa Timur. Pada bulan Juli 2001 dilakukan restrukturisasi kepengurusan Yayasan Miftahul Jannah dan kepesantrenan, termasuk pimpinan pondok. Terhitung sejak bulan Juli 2001 Trimurti Pondok Pesantren Modern Al-Ihsan ditiadakan. Pimpinan Pondok dijabat secara Ex Officio oleh Ketua Umum Yayasan Bapak K.H.U.Muhammad HM. dengan Wakil Pimpinan Drs. H. Mahrus As'ad, M.Ag.

Sejak tahun 2005, Pondok Pesantren Modern Al-Ihsan Baleendah dipimpin oleh seorang pimpinan pesantren dibantu oleh dua orang wakil pimpinan. Mereka adalah:

1. K.H. U. Muhammad HM : Pimpinan Pesantren

2. Dr. H. Mahrus As'ad, M. Ag. : Wakil Pimpinan I (Bidang Pendidikan)

3. H. Uwes Qorni, S.S., M. Pd. : Wakil Pimpinan II (Bidang Administrasi dan Keuangan)

Dengan adanya kepemimpinan kolektif yang terdiri dari tiga orang pemimpin, dibantu dengan pengurus harian yayasan serta para kepala sekolah dan guru-guru, Pesantren Al-Ihsan Baleendah mengalami kamajuan yang cukup pesat, baik dari sisi kuantitas maupun kualitas.

\section{Visi Misi ${ }^{23}$}

${ }^{23}$ Wawancara langsung dengan K.H. U. Muhamad HM. dan Dr. H. Mahrus As'ad, M. Ag., Sabtu, 29 Oktober 2016; lihat juga http:// pesantrenalihsanbe.or.id, diakses pada Senin, 17 Oktober 2016, pukul 10.47 WIB.

\section{a. Visi}

Mempersiapkan Pondok Pesantren

Modern Al-Ihsan terdepan dalam prestasi, mempunyai daya saing, daya sanding, dan Islami dalam budi pekerti.

b. Misi

1) Menjadikan Pondok Pesantren Modern Al-Ihsan sebagai pusat pembelajaran dan pelayanan informasi yang Islami.

2) Membekali warga sekolah keseimbangan wawasan IPTEK, IMTAQ dan life skill (kecakapan hidup), serta bahasa asing untuk menghadapi persaingan global.

3) Menanamkan pada warga sekolah jiwa bekerja ikhlas, keras, cerdas, tangkas, tuntas, ramah, berkwalitas, toleransi dalam perbedaan, dan ahli pikir yang berdzikir.

\section{Struktur Organisasi ${ }^{24}$}

Sistem keorganisasian yang berlaku di Pondok Pesantren Al-Ihsan Baleendah Bandung menetapkan bahwa pimpinan pesantren generasi pertama, masa jabatannya berlaku selama beliau masih siap untuk memimpin pesantren. Sedangkan untuk generasi kedua dan seterusnya masa jabatannya 5 tahun dan bisa diangkat kembali selama masih memenuhi persyaratan yang telah ditentukan. Sedangkan untuk wakil pimpinan, masa jabatannya berlangsung selama 5 tahun, dan bisa diangkat kembali selama masih memenuhi persyaratan yang

${ }^{24}$ Wawancara langsung dengan K.H. U. Muhamad HM. dan Dr. H. Mahrus As'ad, M. Ag., Sabtu, 29 Oktober 2016; lihat juga http:// pesantrenalihsanbe.or.id, diakses pada Senin, 17 Oktober 2016, pukul 10.47 WIB. 
telah ditentukan. Demikian juga masa jabatan direktur KMI dan wakil direktur KMI berlangsung 5 tahun, dan bisa diangkat kembali selama masih memenuhi persyaratan yang telah ditentukan.

Masa jabatan kepala sekolah SLTP dan SLTA, wakil kepala sekolah SLTP dan SLTA, bagian pengajaran KMI, kepala Madrasah Diniyah, wakil kepala Madrasah
Diniyah, kepala TK, wakil kepala TK, ketua pengasuhan santri, dan wakil ketua pengasuhan santri, masa jabatannya berlaku untuk 4 tahun, dan bisa diangkat kembali maksimal sampai 2 (dua) periode masa jabatan.

\section{Struktur Organisasi Pondok Modern Al-Ihsan Baleendah}

Pimpinan Pesantren

Wakil Pimpinan 1

(Bidang Kependidikan )

Wakil Pimpinan 2

(Bidang Administrasi

dan keuangan)

Direktur KMI

Kepala SLTA

Wakil Kepala SLTA

Kepala SLTP

Wakil Kepala SLTP

Ketua Pengasuhan

Kepala TK

Kepala Madrasah Diniyah
: K.H. U. Muhammad HM

: Dr. H. Mahrus As'ad, M. Ag.

: H. Uwes Qorni, S.S., M.Pd.

: H. Dede Rohanda, S.Pd.

: Adad Nursahad, S. Ag.

: Aep Saefudin, S. Pd. I.

: Abun Bunyamin, S.Pd.I.

: Asis Lindarsono, S.Ilkom.

: H. Dede Rohanda, S.Pd.

: Nurhayati, S.Pd., A.UD.

: Inayatillah, S.Pd.

\section{Pengasuhan Santri}

Pembina

Ketua

Majlis Ri'ayah Putra

Majlis Ri'ayah Putri
: Dr. H. Mahrus As'ad, M.Ag.

H. Uwes Qorni, S.S., M.Pd.

: H. Dede Rohanda, S.Pd.

: Adad Nursahad, S. Pd.I.

Aziz Lindarsono S. Ikom

Ahmad Dimyati, S.Pd.

: H. Ahmad Fuad, S. Sos, M.Si.

Siti Saodah, S.Pd.I.

Muhtar Fauzi

Dian Widiati, S.Pd.I 


\section{Unit Kegiatan Pondok ${ }^{25}$}

Unit kegiatan yang dilaksanakan di Pondok Pesantren Al-Ihsan Baleendah Bandung adalah sebagai berikut.
a. TK Islam Plus Miftahul Jannah
b. Madrasah Diniyah Al-Ihsan Baleendah
c. Kulliyatul Mu'allimin al-Islamiyah (KMI) Al-Ihsan Baleendah

d. KBIH (Kelompok Bimbingan Ibadah Haji) Miftahulihsan

e. Amira Tour Haji \& Umrah

f. Baitul Maal lil Ummah (BMU)

g. Koppontren Al-Ihsan

\section{Program Kulliyatul Mu'allimin al- Islamiyah (KMI) Al Ihsan Baleendah \\ 1. Jenjang Pendidikan ${ }^{26}$}

Jenjang pendidikan yang ada di Pondok Modern Al-Ihsan Baleendah adalah KMI (Kulliyatul Mu'allimin alIslamiyah), enam tahun, setingkat Madrasah Tsanawiyah dan Madrasah Aliyah. KMI ini merupakan inti dari lembaga pendidikan Pondok Pesantren Modern Al-Ihsan Baleendah, dan semua siswa KMI pesantren Al-Ihsan Baleendah wajib tinggal di dalam asrama, tidak diperkenankan pulang ke rumah masingmasing setiap hari.

Arti dari Kulliyatul Mu'allimin alIslamiyah adalah persemaian guru-guru Islam. Lembaga KMI berusaha untuk mendidik para santri untuk menjadi guru Agama Islam, dengan pembekalan memadai, yang diharapkan mereka setelah

${ }^{25}$ Wawancara langsung dengan K.H. U. Muhamad HM. dan Dr. H. Mahrus As'ad, M. Ag., Sabtu, 29 Oktober 2016; lihat juga http:// pesantrenalihsanbe.or.id, diakses pada Senin, 17 Oktober 2016, pukul 10.47 WIB.

${ }^{26}$ Wawancara langsung dengan K.H. U. Muhamad HM. dan Dr. H. Mahrus As'ad, M. Ag., Sabtu, 29 Oktober 2016; lihat juga http:// pesantrenalihsanbe.or.id, diakses pada Senin, 17 Oktober 2016, pukul 10.47 WIB. lulus dari KMI dapat mengajar anak-anak tingkat SD dan SLTP dalam bidang agama.

Sesuai dengan jenjang pendidikan yang ada, yaitu KMI 6 tahun, maka kurikulum di Pesantren Al-Ihsan diperuntukan jangka waktu 6 tahun, dari kelas 1 sampai dengan kelas 6 KMI. Dengan demikian, tidak terdapat dua macam kurikulum di KMI, misalnya kurikulum tingkat SLTP (3 tahun) dan SLTA (3 tahun), tetapi kurikulumnya terpadu untuk KMI 6 tahun.

Konsekuensi logis dari sistem yang digunakan di KMI ini adalah, santri dinyatakan lulus apabila sudah menamatkan studinya selama 6 tahun di KMI (dari SD/MI), dan atau 3 tahun (dari SMP/MTs). Ijazah KMI dan ijazah-ijazah lainnya hanya akan diberikan kepada santri yang telah lulus, yaitu mereka yang telah menamatkan studinya dari kelas 6 KMI.

Dalam rangka memenuhi kebutuhan para santri yang ingin melanjutkan studinya ke jenjang yang lebih tinggi, dan supaya KMI memperoleh pengakuan dari pemerintah secara legal formal, maka di akhir kelas 3 KMI, para santri diikutsertakan dalam ujian negara tingkat Tsanawiyah, dan di akhir kelas 6 KMI mereka diikutsertakan dalam ujian negara tingkat Aliyah. Dengan demikian, ketika para santri lulus dari kelas 6 KMI mereka memperoleh tiga ijazah; yaitu ijazah KMI (swasta), ijazah Tsanawiyah (negeri), dan ijazah Aliyah (negeri). Oleh karena itu, lulusan KMI Pesantren Al-Ihsan Baleendah dapat melanjutkan studinya ke berbagai perguruan tinggi negeri dan swasta, baik di dalam maupun di luar negeri. 


\section{Kurikulum $\mathrm{KMI}^{27}$}

Kurikulum KMI Pondok Modern AlIhsan Baleendah merupakan modifikasi dan syntese dari beberapa kurikulum; yaitu kurikulum Departemen Pendidikan Nasional, kurikulum Departemen Agama, dan kurikulum internal pesantren. Untuk pelajaran umum, seperti matematika, fisika, kimia, biologi, sejarah, ekonomi, dan sebagainya, menggunakan kurikulum Depdiknas. Untuk pelajaran agama, mengggunakan kurikulum Depag, kurikulum pondok modern Gontor, dan kurikulum pesantren salaf (tradisional) yang memiliki ciri khas dengan pengajian kitab-kitab Islam klasik (kitab kuning).

Para santri selain belajar secara formal di kelas, juga dibekali dengan berbagai keterampilan, dan life skill yang diajarkan secara ekstrakurikuler. Misalnya keterampilan berorganisasi, komputerisasi, teknologi informasi, kesenian, kemasyarakatan, dan sebagainya. Hal ini dimaksudkan sebagai bekal para santri setelah menyelesaikan studinya dari pesantren untuk kembali ke masyarakat, sehingga mereka mampu berdikari dan tidak menggantungkan nasibnya kepada orang lain.

Kurikulum di KMI pondok modern AlIhsan tidak hanya berupa mata pelajaran yang diajarkan di kelas, tetapi mencakup seluruh aktivitas santri, baik ketika di kelas, di asrama, di masjid, di lapangan olahraga, dan sebagainya. Seluruh kegiatan yang dapat mengantarkan pesantren untuk mencapai tujuan pendidikannya, termasuk kurikulum

${ }^{27}$ Wawancara langsung dengan KH. U. Muhamad HM. dan Dr. H. Mahrus As'ad, M. Ag., Sabtu, 29 Oktober 2016; lihat juga http:// pesantrenalihsanbe.or.id, diakses pada Senin, 17 Oktober 2016, pukul 10.47 WIB. pesantren. Oleh karena itu, seluruh aktivitas yang diikuti, dilihat, dan didengar oleh santri semuanya dimaksudkan untuk pendidikan.

\section{Metode Pendidikan dan Pengajaran ${ }^{28}$}

Metode pendidikan dan pengajaran yang digunakan di Pondok Pesantren Modern Al-lhsan tidak jauh berbeda dengan metode yang diterapkan di Pondok Modern Gontor. Pendidikan tidak hanya dilaksanakan di dalam kelas, tetapi di semua aktivitas santri, baik ketika mereka berada di asrama, di masjid, di perpustakaan, maupun di lapangan olah raga, semuanya dimaksudkan untuk pendidikan.

Dalam aspek kependidikan, di Pondok Pesantren Modern Al-Ihsan diterapkan.

1. Sistem asrama; seluruh santri berada di asrama yang harus mengikuti disiplin dan sunnah Pondok Pesantren Modern Al-Ihsan.

2. Learning by doing; segala sesuatu yang diajarkan harus langsung diamalkan dan dipraktekkan

3. Bahasa Arab dan Inggris dijadikan sebagai bahasa resmi santri baik ketlka mengikuti KBM maupun sebagai alat komunikasi sehari-hari.

4. Uswatun hasanah; para pengasuh dan pendidik senantiasa memberi teladan yang baik dalam segala hal kepada para santrinya.

5. Ruh keikhlasan; kyai dan pengasuh ikhlash mendidik, santri ikhlash dididik, ditegur, diingatkan, dan diberi sangsi apabila melanggar.

${ }^{28}$ Wawancara langsung dengan Ust. Samadi, Ust. Dena dan Ust. Yusuf, bagian Penanggungjawab Pembinaan Santri, Sabtu, 29 Oktober 2016; lihat juga http:/ pesantrenalihsanbe.or.id, diakses pada Senin, 17 Oktober 2016, pukul 10.47 WIB. 
Santri tidak hanya ikhlash ditegur oleh kyai dan pengasuh, tetapi juga oleh temannya.

Sedangkan dalam aspek pengajaran, di Pondok Pesantren Modern Al-Ihsan diterapkan sistem, metode, dan pendekatan-pendekatan seperti yang diterapkan di sekolah-sekolah yang lain, namun bahasa pengantar yang digunakan dalam kegiatan belajar mengajar adalah Bahasa Arab dan Bahasa Inggris. Pengajaran bahasa Arab dan bahasa Inggris menggunakan sistem direct mothode (metode langsung), yaitu metode tanpa terjamah. Artinya, pelajaran disampaikan dengan bahasa Arab atau bahasa Inggris secara langsung, tanpa diterjemahkan ke dalam bahasa Indonesia.

Bahasa Arab dan bahasa Inggris adalah mahkota pesantren. Untuk menunjang pengajaran bahasa Arab dan bahasa Inggris, disediakan laboratorium bahasa. Namun yang paling penting adalah kesadaran santri untuk selalu menggunakan kedua bahasa tersebut dalam percakapan sehar-hari. Apabila santri hanya berbahasa resmi ketika berada di laboratorium bahasa, dan ketika berada di luar laboratorium tidak menggunakan bahasa resmi, maka pengajaran bahasa tidak akan berhasil dengan baik.

Untuk menunjang peningkatan kemampuan santri dalam sains dan iptek, disediakan ruang audio visual yang dapat digunakan dalam proses pembelajaran online via internet. Selain itu juga dilengkapi dengan berbagai laboratorium ilmu pengetahuan alam, seperti laboratorium fisika, laboratorium kimia, dan laboratorium biologi. Kesemua sarana tersebut dimaksudkan untuk memudahkan para santri dalam meningkatkan kemampuan sains dan teknologi mereka, sehingga tidak "gaptek" menghadapi dunia teknologi seperti sekarang ini.

\section{Pola Pembinaan ${ }^{29}$}

Pola pembinaan yang digunakan dalam proses pendidikan dan pembelajaran di Pondok Pesantren Modern Al-Ihsan Baleendah terbagi menjadi dua macam. Pertama, pembinaan yang dilakukan kepada para santri pada saat jam belajar formal di dalam kelas, yaitu dari jam 07.00 - 14.30. Kedua, pembinaan yang dilakukan kepada para santri di luar jam belajar formal, yaitu dari jam 14.30 - 07.00 pagi. Pola pembinaan yang dilakukan di Pesantren Al-Ihsan, baik pada saat belajar formal maupun non-formal, seluruhnya berorientasi kepada kepentingan anak didik (student centered).

Pembinaan santri selama proses bembelajaran formal di kelas ditangani oleh Direktur KMI beserta jajarannya; yaitu Wakil Direktur KMI, kepala MA dan wakilnya, kepala MTS dan wakilnya, bagian pengajaran, Guru BP, dan seluruh staf pengajar. Pembinaan lebih mengutamakan pencegahan agar anak didik tidak melakukan berbagai palanggaran, daripada perbaikan setelah terjadinya pelanggaran yang mereka lakukan. Pola pembinaan ini menuntut kepala sekolah dan para guru proaktif terhadap peserta didik, agar pembinaan dapat mencapai hasil yang maksimal.

Adapun pembinaan santri di luar jam belajar formal berada di bawah tanggung jawab bagian pengasuhan dan seluruh guru

\footnotetext{
${ }^{29}$ Wawancara langsung dengan Ust. Samadi, Ust. Dena dan Ust. Yusuf, bagian Penanggung jawab Pembinaan Santri, Sabtu, 29 Oktober 2016; http://pesantrenalihsanbe.or.id, diakses pada Senin, 17 Oktober 2016, pukul 10.47 WIB.
} 
dalam (guru yang tinggal di asrama pesantren). Pembinaan ini waktunya lebih panjang, dan mekanismenya lebih rumit karena mencakup seluruh kehidupan santri, mulai dari keluar sekolah jam 13.30 sore sampai masuk kelas jam 07.00 pagi hari berikutnya.

Untuk memudahkan pembinaan para santri agar memperoleh hasil yang maksimal, maka pembinaan diklasifikasi menjadi beberapa katagori; antara lain pembinaan dalam shalat berjamaah, membaca Al-Qur'an, pengontrolan belajar malam, pelajaran ekstrakurikuler, olahraga, muhadharah, disiplin bahasa, disiplin keluar pondok, dan displin kehidupan di dalam pondok. Pembinaan di setiap kategorisasi di atas dilakukan oleh para pembina yang terdiri dari para ustadz bagian pengasuhan santri, dan juga dibantu oleh pengurus organisasi santri, baik organisasi santri putra (OPPMAI), maupun organisasi santri putri (OP3MAI).

Unsur yang utama dalam pembinaan ini adalah uswah hasanah (teladan yang baik) dari pembina. Para pembina, baik dari para ustadz maupun dari pengurus organisasi santri harus memberikan contoh yang baik kepada seluruh santri. Sebab seluruh kehidupan yang dilihat oleh santri, didengar dan dilakukan oleh mereka adalah pendidikan. Apabila yang dilihat dan didengar, oleh santri adalah hal-hal yang baik, maka akan tertanam dalam diri mereka pendidikan yang baik pula.

Dengan demikian, keberhasilan pendidikan para santri sangat tergantung kepada contoh dan teladan yang diberikan oleh para ustadz dan pembina, yang akan memiliki dampak yang cukup besar dalam proses pembentukan kepribadian para santri.

\section{Kegiatan Santri ${ }^{30}$}

Santri Pesantren Al-Ihsan Baleendah wajib tinggal di dalam asrama, dan tidak diperbolehkan pulang ke rumah masingmasing setiap hari, meskipun rumahnya hanya berjarak $100 \mathrm{M}$ dari pesantren. Seluruh santri termasuk santri mukim (tinggal di asrama), dan tidak ada santri kalong (yang pulang pergi ke rumah). Hal ini dimaksudkan untuk memberikan lingkungan yang kondusif bagi pendidikan para santri, dan tidak mudah terkena pengaruh dari lingkungan di luar pesantren.

Dengan demikian, pendidikan di Pesantren Al-Ihsan Baleendah berlangsung selama 24 jam dalam sehari, karena seluruh aktivitas santri dimaksudkan untuk pendidikan. Santri dalam kesehariannya menjalani berbagai aktivitas yang cukup padat, tidak ada waktu yang terbuang kosong, tanpa dimanfaatkan untuk hal-hal yang positif, baik dalam mengikuti kegiatan kurikuler mapun ekstra kurikuler.

Berikut ini jadwal kegiatan yang dilakukan para santri setiap hari.

04.00 : Bangun Pagi, Shalat Subuh, Membaca Al-Qur'an, dan Intensifikasi Bahasa

05.00 : Mengulangi Pelajaran, Olah Raga, Mandi

06.00 : Makan Pagi, Persiapan Masuk Kelas

07.00 : Masuk Kelas

12.00 : SHALISKAN (Shalat, Istrirahat, Makan)

13.15 : Masuk Kelas Siang

14.30 : Persiapan Shalat Ashar

${ }^{30}$ Wawancara langsung dengan Ust. Samadi, Ust. Dena dan Ust. Yusuf, bagian Penanggung jawab Pembinaan Santri, Sabtu, 29 Oktober 2016; lihat juga http://pesantrenalihsanbe.or.id, diakses pada Senin, 17 Oktober 2016, pukul 10.47 WIB. 
15.00: Shalat Ashar

15.30 : Olah Raga, Kursus dan Lain-lain

17.00 : Mandi Sore, Persiapan Shalat Magrib

17.00 : Pengajian Kitab Kuning, Tahsin Al-Qur'an

18.00 : Shalat Magrib, membaca AlQur'an

18.30 : Makan Malam

19.00 : Shalat Isya

19.30 : Belajar Malam

21.30 : Tidur Malam

\section{Jadwal Kegiatan Santri Mingguan}

Jum'at:

Muhadharah (Latihan Pidato) Bahasa

Arab, Latihan Pramuka

Ahad:

Muhadatsah (Percakapan) Bahasa Arab /

Bahasa Inggris, Lari Pagi/Senam, Kegiatan Olahraga Lainnya, Pembersihan Umum.

Selasa Malam :

Muhadharah Bahasa Inggris

Kamis Malam :

Muhadharah Bahasa Indonesia

\section{Ekstrakulikuler}

Ekstrakulikuler adalah pendidikan dan keterampilan yang diberikan kepada para santri di luar jam belajar di kelas. Hal ini dimaksudkan untuk membekali para santri dengan keterampilan praktis yang sangat diperlukan dalam kehidupan mereka untuk dapat mengantisipasi kebutuhan zaman yang terus mengalami kemajuan dengan pesat.

Ekstrakurikuler yang diberikan di Pesantren Al-Ihsan Baleendah adalah: a. Komputerisasi (IT)

b. Pramuka/PMR/Paskibra

c. Organisasi Santri OPPMAI/OP3MAI

d. Muhadlarah Tiga Bahasa: Arab, Inggris, dan Indonesia.

e. Bela Diri Pencak Silat

f. Kursus Electro

g. Kursus Kesenian:

1) Keyboard,

2) Nasyid,

3) Marawis

4) Vokal

5) Paduan Suara

6) Kaligrafi

7) Seni Baca Al-Qur'an

h. Kursus Olahraga:

1) Sepak bola

2) Basket

3) Bulutangkis

4) Volly

5) Tenis Meja

i. Keputrian:

1) Tata Boga

2) Tata Busana

3) Menjahit

4) Bordir/Sulam

\section{N. Perencanaan Pembelajaran KMI}

Perencanaan pembelajaran merupakan aspek penting dan mendasar dalam setiap pembelajaran. Baik dan buruknya kualitas pelaksanaan pembelajaran salah satu faktornya dipengaruhi oleh perencanaan pembelajaran. Setiap jalur pendidikan formal, nonformal, dan informal mempunyai cara tersendiri dalam menyusun perencanaan pembelajaran. Pondok Pesantren Al-Ihsan Baleendah Bandung, termasuk jenis pendidikan keagamaan yang diselenggarakan dalam jalur pendidikan formal, mempunyai cara tertentu dalam penyusunan perencanaan pembelajaran. 
Ustad Dr. H. Mahrus As'ad M.Ag., pada saat wawancara tanggal 29 Oktober 2016 menyatakan: ${ }^{31}$

"Kurikulum KMI diselenggarakan selama 6 tahun dalam jenjang formal setingkat MTS dan MA, struktur kurikulum disusun mengikuti format kurikulum MTS dan MA, dipadukan dengan kurikulum Depag, kurikulum Depdiknas, kurikulum Pondok Modern Gontor, dan kurikulum pesantren tradisional. Selanjutnya dalam perencanaannya seluruh materi tersebut dirumuskan dan diturunkan ke dalam struktur kurikulum sesuai dengan jenjang level 1 sampai level 6 dalam bentuk Silabus. Diturunkan lagi ke dalam sebaran jadwal dan kegiatan pembelajaran tatap muka dalam bentuk RPP, sehingga dapat dilaksanakan pada tingkat pembelajaran harian".

Kompetensi yang ingin dibentuk di pesantren ini adalah menjadi guru agama Islam. Hal ini membuat pengurus Pondok Pesantren Al-Ihsan Baleendah Bandung menginventarisir materi pelajaran dan membagi dalam struktur pembelajaran tersendiri dengan harapan mampu mencetak santrinya menjadi guru agama Islam yang dapat mengajar anak-anak tingkat SD dan SLTP di masyarakat.

Keterangan ini diperoleh saat wawancara dengan Ustad Dr. H. Mahrus As'ad M.Ag., pada saat wawancara tanggal 29 Oktober 2016, beliau menjelaskan: ${ }^{32}$

"Sesuai arti dari Kulliyatul Mu'allimin AlIslamiyah, maka tujuan yang ingin dicapai adalah persemaian guru-guru Islam. Sehingga KMI berusaha untuk mendidik para santri untuk menjadi guru Agama

\footnotetext{
31 Wawancara dengan Dr. H. Mahrus As'ad, M. Ag., Sabtu, 29 Oktober 2016.

${ }_{32}$ Wawancara dengan Dr. H. Mahrus As'ad, M. Ag., Sabtu, 29 Oktober 2016.
}

Islam, dengan pembekalan memadai, yang diharapkan mereka setelah lulus dari KMI dapat mengajar anak-anak tingkat SD dan SLTP dalam bidang agama Islam.

Adapun format kurikulum yang dibuat Pondok Pesantren Al-Ihsan Baleendah Bandung sebagaimana dijelaskan Ustad Dr. H. Mahrus As'ad M.Ag.: ${ }^{33}$

Kurikulum KMI beberapa kali mengalami perubahan, hal tersebut disesuaikan dengan permintaan dan kebutuhan orangtua santri yang menginginkan anaknya mendapatkan pendidikan keagamaan sekaligus mendapatkan ijazah sekolah formal agar dapat memiliki keterjaminan untuk melanjutkan ke jenjang pendidikan lebih tinggi lagi. Kurikulum KMI diselenggarakan selama 6 tahun dalam jenjang formal setingkat MTS dan MA. Sehingga susunan materi pelajaran mengikuti format kurikulum MTS dan MA, dipadukan dengan kurikulum Depag, kurikulum Depdiknas, kurikulum Pondok Modern Gontor, dan kurikulum pesantren tradisional.

\section{O. Pelaksanaan Pembelajaran KMI}

Proses belajar mengajar merupakan substansi inti dari pelaksanaan pembelajaran. Berdasarkan hasil observasi lapangan terhadap pembelajaran yang dilakukan pada tanggal 26 Oktober 2016.

Pelaksanaan proses belajar mengajar secara rutin dilakukan setiap hari SeninSabtu jam 04.00--21.30, sedangkan kegiatan tambahan dilakukan pada hari Jum'at, kegiatan muhadharah (latihan pidato) Bahasa Arab, latihan Pramuka, hari Ahad kegiatan Muhadatsah (percakapan) Bahasa Arab/Bahasa Inggris, Selasa Malam Muhadharah

${ }^{33}$ Wawancara dengan Dr. H. Mahrus As'ad, M. Ag., Sabtu, 29 Oktober 2016. 
Bahasa Inggris, Kamis Malam, dan Muhadharah Bahasa Indonesia.

Sedangkan tahapan proses belajar mengajar yang dilakukan Pondok Pesantren Al-Ihsan Baleendah Bandung adalah:

1. Kegiatan awal

a. Pembukaan dimulai dengan ucapan salam dilanjutkan doa sebelum pelajaran dimulai yang dipimpin oleh ustad atau pengajar.

b. Pretest dilakukan ustad untuk mengetahui kefahaman santri terhadap materi pelajaran yang diberikan, sekaligus mengulang pelajaran secara singkat sebelum masuk ke materi inti.

2. Kegiatan inti

a. Ustad langsung menjelaskan ke pokok materi pelajaran. Kegiatan tidak dimulai dengan menjelaskan tujuan pengajaran dan pokok-pokok materinya yang akan diberikan setiap pertemuan. Hal ini disebabkan karena padatnya mata pelajaran sehingga pembelajaran dituntut efektif dan efesien dalam hal waktu.

b. Metode penyampaian materi yang digunakan ceramah klasikal, tanya jawab, interaktif, demonstrasi, role play dan praktek. Metode interaktif terutama digunakan pada mata pelajaran Bahasa Arab, Bahasa Inggris, Tahsin serta Tahfidz Al Quran. Adapun untuk metode demontrasi dan role play atau kegiatan bermain peran dipraktikkan pada kegiatan muhadhoroh atau latihan ceramah dan latihan khutbah.

c. Kegiatan pembelajaran, para ustad atau pengajar menggunakan alat bantu seperti laptop, LCD, white board, spidol untuk memudahkan para santri dalam memahami mata pelajaran.

d. Ustad menyimpulkan materi pelajaran. Biasanya ditutup dengan meringkas beberapa poin materi yang disampaikan.

\section{Kegiatan akhir}

a. Membuka sesi tanya jawab kepada para santri apabila belum jelas materi yang disampaikan.

b. Ustad memberitahu materi yang akan dibahas dan dikaji pada pertemuan berikutnya.

c. Menutup proses belajar mengajar dengan doa bersama penutup majelis ilmu.

d. Ustad mengucapkan salam penutup.

\section{P. Evaluasi Pembelajaran}

Bentuk evaluasi pembelajaran dapat dibedakan menjadi evaluasi formatif dan evaluasi sumatif. Evaluasi formatif adalah penilain berupa tes (soal-soal atau pertanyaan) yang diselenggarakan setelah satu pokok bahasan selesai dipelajari peserta didik. Evaluasi sumatif adalah penilaian berupa tes yang dilakukan setelah proses belajar mengajar selesai dalam jangka waktu tertentu, misalnya satu semester atau satu caturwulan.

Sistem penilaian mata pelajaran yang digunakan di pesantren ini dilakukan setiap selesai mata pelajaran, sebagai ulangan harian, kemudian penilaian pada tengah semester dan penilaian yang dilaksanakan setiap selesai semester serta penilaian yang dilakukan pada akhir tahun atau disebut juga ujian kenaikan kelas. Penilaian pelajaran dilakukan sesuai target standar kompetensi yang telah ditetapkan dalam program semester dan program 
tahunan sebagaimana tertuang dalam silabus dan RPP.

Hasil wawancara dan observasi lapangan, Pondok Pesantren Al-Ihsan Baleendah Bandung menerapkan evaluasi formatif yaitu evaluasi yang dilakukan setiap selesai pelaksanaan pembelajaran pada mata pelajaran Tahsin atau perbaikan bacaan AlQur'an, Muraja'ah (menyetor hafalan AlQur'an dan Al-Hadist), dan muhadharah atau latihan ceramah atau khutbah.

\section{Q. Kesimpulan}

Berdasarkan penyajian data dan hasil yang telah dijelaskan sebelumnya, maka kesimpulan penelitian ini adalah:

\section{Perencanaan Pembelajaran di Pondok Pesantren Al Ihsan Baleendah Bandung.}

Proses perencanaan pembelajaran disusun dalam format program tahunan (PROTAH) dan program semester (PROSEM), yang termuat di dalam Buku 1 dan Buku 2 kurikulum sekolah, yang memuat perencanaan Silabus dan RPP seluruh materi yang kemudian dirumuskan dan diturunkan ke dalam struktur kurikulum sesuai dengan jenjang level 1 sampai level 6 dalam bentuk Silabus. Diturunkan lagi ke dalam sebaran jadwal dan kegiatan pembelajaran tatap muka dalam bentuk RPP, sehingga dapat dilaksanakan pada tingkat pembelajaran harian.

\section{Pelaksanaan Pembelajaran di Pondok Pesantren Al Ihsan Baleendah Bandung.}

Pelaksanaan proses belajar mengajar secara rutin dilakukan setiap hari SeninSabtu jam 04.00--21.30, sedangkan kegiatan tambahan dilakukan pada hari Jum'at, kegiatan muhadharah (latihan pidato) Bahasa Arab, latihan Pramuka, hari Ahad kegiatan Muhadatsah (percakapan) Bahasa Arab/Bahasa Inggris, Selasa Malam Muhadharah Bahasa Inggris, Kamis Malam Muhadharah Bahasa Indonesia.

Sedangkan tahapan proses belajar mengajar yang dilakukan di Pondok Pesantren Al-Ihsan Baleendah Bandung dilaksanakan melalui rangkaian kegiatan awal, kegiatan inti, kegiatan akhir. Ustad menyampaikan materi dengan metode ceramah klasikal, tanya jawab, interaktif, demonstrasi, role play, dan praktik. Metode interaktif terutama digunakan pada mata pelajaran Bahasa Arab, Bahasa Inggris, Tahsin serta Tahfidz Al-Quran. Adapun untuk metode demontrasi dan role play atau kegiatan bermain peran dipraktikkan pada kegiatan muhadharah atau latihan ceramah dan latihan khutbah.

Kegiatan pembelajaran, para ustad atau pengajar menggunakan alat bantu seperti laptop, LCD, white board, spidol untuk memudahkan para santri dalam memahami mata pelajaran.

\section{Evaluasi Pembelajaran di Pondok Pesantren Al Ihsan Baleendah Bandung.}

Pesantren ini menggunakan evaluasi formatif dan evaluasi sumatif. Pondok Pesantren Al-Ihsan Baleendah Bandung menerapkan evaluasi formatif yaitu evaluasi yang dilakukan setiap selesai pelaksanaan pembelajaran pada mata pelajaran Tahsin atau perbaikan bacaan Al-Qur'an, Muraja'ah (menyetor hafalan Al-Qur'an dan Al-Hadist), dan muhadharah atau latihan ceramah atau khutbah.

Sedangkan evaluasi sumatif dilakukan dilakukan setiap selesai mata pelajaran sebagai ulangan harian, kemudian penilaian pada tengah semester dan 
penilaian yang dilaksanakan setiap selesai semester serta penilaian yang dilakukan pada akhir tahun atau disebut juga ujian kenaikan kelas. Penilaian pelajaran dilakukan sesuai target standar kompetensi yang telah ditetapkan dalam program semester dan program tahunan sebagaimana tertuang dalam silabus dan RPP.

\section{Daftar Pustaka}

Ambarita, Alben. (2006). Manajemen Pembelajaran. Jakarta: Departemen Pendidikan Nasional.

Alsa, Asmadi. (2007). Pendekatan Kuantitatif dan Kualitatif serta Kombinasinya dalam Penelitian Psikologi. Yogyakarta: Pustaka Pelajar.

Sarkowi, Imam. (2011). Pembaharuan Pemikiran Pesantren. Diakses dari http://saintek.uin-

malang.ac.id/index.php/artikel-1/460-

pembaharuan-pemikiran-pesantren.html. pada tanggal 2 Januari 2012

Lexy J, Moleong. (2005). Metodologi Penelitian Kualitatif. Bandung: PT Remaja Rosdakarya.

Mulyasa. (2006). Kurikulum Tingkat Satuan Pendidikan. Bandung: PT Remaja Rosdakarya.

Sudjana, Nana. (2010). Dasar-Dasar Proses Belajar Mengajar. Bandung: Sinar Baru Algensindo.

Nasir, Ridlwan. (2005). Mencari Tipologi Format Pendidikan Ideal: Pondok Pesantren di Tengah Arus Perubahan. Yogyakarta: Pustaka Pelajar.
Sugiyono. (2007). Metode Penelitian Kuantitatif Kualitatif dan $R \quad \& \quad D$. Bandung: Alfabeta.

Arikunto, Suharsimi. (2006). Prosedur Penelitian: Suatu Pendekatan Sistem. Jakarta: PT Rineka Cipta. (2005). Dasar-Dasar

Evaluasi Pendidikan. Jakarta: PT Bumi Aksara.

(2002). Prosedur

Penelitian. Jakarta: PT Asdi Mahasatya.

Sulthon Masyhud dan Khusnurdilo. (2003). Manajemen Pondok Pesantren. Jakarta: Diva Pustaka Jakarta.

Saputro, Suprihadi. (2000). Strategi Pembelajaran. Malang: Departemen Pendidikan Nasional, Universitas Negeri Malang.

Syaiful Bahri dan Azwan Zain. (2010). Setrategi Belajar Mengajar. Jakarta: Rineka Cipta.

Amirin, Tatang M. (2009). Subjek Penelitian, Responden Penelitian, dan Informan (Narasumber) Penelitian. Diakses dari http://tatangmanguny. wordpress.com/ 2009/04/21/subjek-responden-daninforman-penelitian/. pada tanggal 25 Oktober 2016, pukul 11.07 wib.

Dhofier, Zamakhsyari. (1983). Tradisi Pesantren: Studi tentang Pandangan Hidup Kyai. Jakarta: LP3S. 


\section{Lampiran}

\section{DOKUMENTASI}

\section{A. Fasilitas}
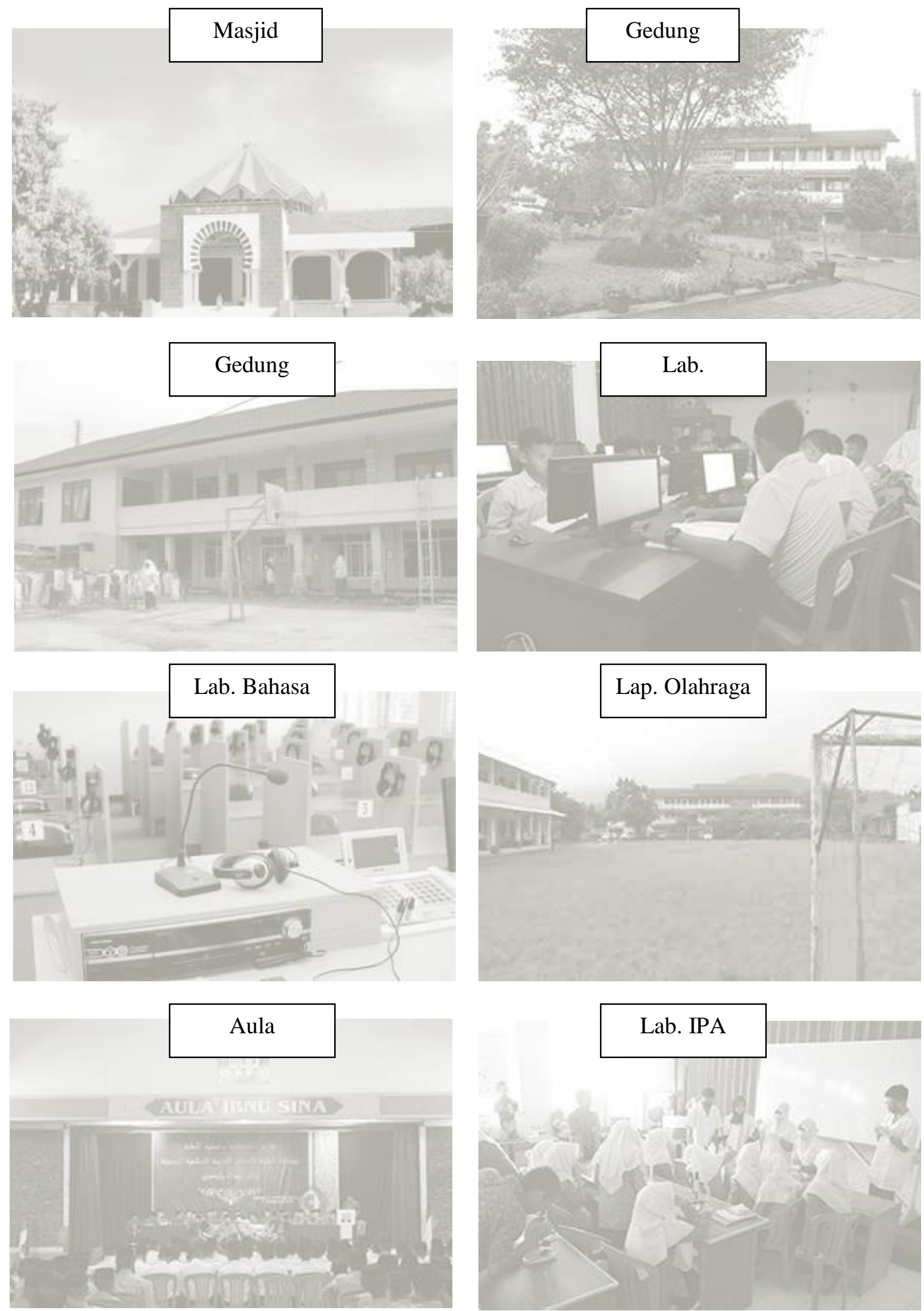